\title{
Detection of the mitochondrial and catalytically active alanine aminotransferase in human tissues and plasma
}

\author{
BJÖRN GLINGHAMMAR ${ }^{1}$, INGALILL RAFTER ${ }^{1}$, ANNA-KARIN LINDSTRÖM ${ }^{2}$, JESPER J. HEDBERG ${ }^{1}$, \\ HÅKAN B. ANDERSSON ${ }^{3}$, PER LINDBLOM ${ }^{1}$, ANNA-LENA BERG ${ }^{2}$ and IAN COTGREAVE ${ }^{1}$ \\ ${ }^{1}$ Safety Assessment, Molecular Toxicology, AstraZeneca, S-151 85 Södertälje; ${ }^{2}$ Safety Assessment, Pathology, \\ AstraZeneca R\&D; ${ }^{3}$ Safety Assessment, Clinical Pathology, AstraZeneca R\&D, Södertälje, Sweden
}

Received December 5, 2008; Accepted January 16, 2009

DOI: 10.3892/ijmm_00000173

\begin{abstract}
Serum alanine aminotransferase (ALT) is used as a clinical marker of hepatotoxicity. Three forms of human ALT have been identified, ALT1 and 2 and an alternative splice variant of ALT2 (herein called ALT2_2). The standard ALT activity assay does not discriminate between ALT from different organs, or the isoforms measured in the plasma. Here, we show that ALT1 and 2 possess similar enzymatic activity for alanine and pyruvate but with different $\mathrm{K}_{\mathrm{m}}$ and $\mathrm{k}_{\text {cat }}$ values, while recombinant ALT2_2 protein does not possess any enzymatic activity. Isolation of organelles from cultured human skeletal muscle cells, showed localisation of ALT2 to the mitochondrial fraction and endoplasmatic reticulum (ER), but not to the cytosol. In human hepatocytes, on the other hand, ALT1 was only localised to the cytosol and ER, with no detection in mitochondria. ALT2 was not detected in cultured human hepatocytes, liver extract or tissue using Western blotting or immunohistochemistry. The islet of Langerhans and cardiomyocytes were other examples of cells with high expression of catalytic ALT2. A clinical method for selective measurement of ALT1 and 2 in human plasma is described, and both ALT1 and 2 were immunoprecipitated from human plasma and structurally detected using Western blotting techniques.
\end{abstract}

\section{Introduction}

Alanine aminotransaminase (ALT, ALAT, also known as glutamate pyruvate transaminase, GPT) is an enzyme that catalyses the reversible transfer of the amino group of alanine to the $\alpha$-ketogroup of ketoglutaric acid to generate glutamate and pyruvate. By mediating conversion of these four intermediate metabolites, ALT serves as an important contributor to gluconeogenesis and amino acid metabolism. Earlier studies

Correspondence to: Dr Björn Glinghammar, Safety Assessment, Molecular Toxicology, AstraZeneca, S-151 85 Södertälje, Sweden E-mail: bjorn.glinghammar@astrazeneca.com

Key words: liver, hepatotoxicity, biomarker, ALT, ALAT, GPT2, serum, plasma, tissue expression indicate the existence of two isoforms of ALT, although this was not resolved until Swick et al characterized cytosolic and mitochondrial forms in rat and porcine tissue homogenates (1-3). The complete amino acid sequence (495 aa) for ALT1 has been known for some time (4). However, the human GPT2 was cloned and its mRNA expression confirmed about 11 years later (5). The human ALT genes, GPT1 and 2, are located on chromosomes 8 and 16, respectively, and differential splicing of the GPT2 gene yields either a protein of 523 amino acids or, due to an alternative translational start codon usage, a shorter protein product of 423 amino acids (5-7).

Analysis of serum ALT activity levels is routinely used for detecting liver injury, a biomarker that has been in use for more than 50 years (8). Similarly, in preclinical testing of drug candidates, the increased ALT enzymatic activity in serum is mainly used as an index of hepatocellular damage. In many instances, testing of drug candidates sometimes gives serum ALT elevations in preclinical species without overt histopathological evidence of liver damage (9-11). In addition, other drugs, such as oxodipine, actually decrease serum ALT and aspartate aminotransferase (AST) in association with hepatic damage in both dogs and rats (12). Furthermore, drugs like cefazolin and isoniazid also decreases serum ALT or AST activity in several studied animal species $(13,14)$. In theory, when serum ALT increases without involving liver injury, it is due to at least two things; either more ALT enzyme is produced in the liver due to metabolic adaptation/induction or ALT is released from an extrahepatic organ suffering from injury. Hence, there is a need to understand more about what regulates ALT and to study the presence of ALT isoforms in extrahepatic organs.

We provide new data of the relative enzymatic abilities and substrate preferences by the different ALT enzymes. Furthermore, we show cellular localisation of catalytic ALT1 and 2 in hepatocytes and cultured skeletal muscle cells. In addition to intracellular localisation, we identified tissues that harbour the highest expression of the catalytically active ALT2 isoform, as well as its detection in human plasma for the first time.

The standard ALT activity assay does not discriminate between ALT from different organs, or the isoforms measured in the plasma or serum. An assay that measures both ALT1 and 2 proves valuable in discriminating human liver injury from other extrahepatic tissue damage. 


\section{Materials and methods}

Tissue and cell culture. Normal human tissue lysates from the liver (GTX27931) and heart (GTX27916) were obtained from GeneTex, TX, USA. Cryopreserved human hepatocytes from three different donors (IEM, IZG and GIU) were obtained from In Vitro Technologies (Baltimore, MD, USA). Cells were maintained in DMEM (1 g/l glucose) with 10\% FBS, $100 \mathrm{U} / \mathrm{ml}$ penicillin and $100 \mu \mathrm{g} / \mathrm{ml}$ streptomycin, $1 \%$ non-essential amino acids (Gibco) in a humidified atmosphere of $95 \%$ air, $5 \% \mathrm{CO}_{2}$ at $37^{\circ} \mathrm{C}$. Human skeletal muscle cells, Hs94.T (ATCC no. CRL-7064), were purchased from ATCC (Rockville, MD, USA). Cells were maintained in DMEM, $4.5 \mathrm{~g} / 1$ glucose with $10 \% \mathrm{FBS}, 100 \mathrm{U} / \mathrm{ml}$ penicillin and $100 \mu \mathrm{g} / \mathrm{ml}$ streptomycin, $1 \%$ non-essential amino acids (Gibco) in a humidified atmosphere of $95 \%$ air, $5 \% \mathrm{CO}_{2}$ at $37^{\circ} \mathrm{C}$.

cDNA cloning, expression and purification of ALT1, 2 and 2_2. We recently cloned and expressed the two forms of human GPT1 and 2 (6). The cDNA for GPT1 (\#T0604), GPT2 (\#Y4158), GPT2_2 (\#T6281) and Enhanced Green Fluorescent Proteins $(e G F P)$ served as the control in the vector, pReceiverB01 using T7 as promoter and 6xHis-tag for this study, were obtained from Genecopedia, USA. The competent E. coli strain, BL21 Star (DE3)pLysS One shot (Invitrogen), was transformed with either Ex-T0604-B01, Ex-Y4158-B01, Ex-T6281-B01 or Ex-EGFP-B01. The entire transformation reactions were added to $10 \mathrm{ml}$ of Luria-Bertani (LB) containing ampicillin $(50 \mu \mathrm{g} / \mathrm{ml})$. Cultures were grown overnight at $37^{\circ} \mathrm{C}$ with shaking. The overnight cultures were used to inoculate a $250 \mathrm{ml}$ culture of LB-ampicillin containing a cocktail of protease inhibitors (Complete Mini, Roche, Mannheim, Germany) that were grown at $37^{\circ} \mathrm{C}$ until an OD600 of 0.5 , at which time isopropyl-thiogalactopyranoside (IPTG) was added ( $1 \mathrm{mM}$, final concentration) to induce expression of recombinant 6xHis-ALT1, 2 and 2_2. Growth was continued at $37^{\circ} \mathrm{C}$ for an additional $4 \mathrm{~h}$. Cells were harvested by centrifugation at $4000 \mathrm{x} \mathrm{g}$ for $20 \mathrm{~min}$. The cells were kept as a frozen cell pellet overnight at $-20^{\circ} \mathrm{C}$. Recombinant His-tagged ALT1, 2 and 2_2 proteins were purified under native conditions according to QIAexpress NI-NTA Fast Start Handbook (04/2005) from Qiagen. All fractions were analysed by SDSPAGE, Sypro Ruby-stained and blotted with specific ALT1 and 2 antibodies. The His-tags were not removed from the recombinant proteins. Protein concentrations were determined using BioRad Protein assay. ALT activity from purified recombinant proteins was measured according to the International Federation of Clinical Chemistry (IFCC) with pyridoxal phosphate activation (ALTLP: ACN 684, Cobas, Roche). Enriched recombinant proteins were stored at $-80^{\circ} \mathrm{C}$ in ALT buffer, containing phosphate buffered saline (PBS), $1 \mathrm{mg} / \mathrm{ml} \mathrm{BSA}$ and $25 \%$ glycerol, until further use.

Protein analysis. The subcellular fractions, human liver and heart extracts, recombinant proteins and serum/plasma immunoprecipitates were boiled for $5 \mathrm{~min}$ in $1 \mathrm{x}$ SDS sample buffer (50 mM Tris-HCl pH 6.8, $12.5 \%$ glycerol, $1 \%$ sodium dodecylsulfate, $0.01 \%$ bromophenol blue) containing $5 \%$ ß-mercaptoethanol. Whole cell extracts from Hs94.T cells were made using lysis buffer (10 mM HEPES-KOH pH 7.9, $1.5 \mathrm{mM}$
$\mathrm{MgCl}_{2}, 10 \mathrm{mM} \mathrm{KCl}, 0.5$ mM DTT, 0.2 mM PMSF, 0.1\% NP40 and protease inhibitors, Complete Mini, Roche, Mannheim, Germany). The protein extracts were subjected to SDS-polyacrylamide gel electrophoresis, performed under reducing conditions on $12 \%$ Tris-Glycine gels. The resolved proteins were transferred to a nitrocellulose sheet and subjected to Ponceau staining. The staining intensity was consistently identical in all lanes. The ALT1 and 2 antibodies used were described previously (6). For some experiments, two commercial ALT2 antibodies were used (sc-46352 and sc-46350, Santa Cruz, USA). The nitrocellulose membrane was then incubated with rabbit polyclonal antibodies against ALT1 (Ab10995, $0.1 \mu \mathrm{g} / \mathrm{ml}$ dilution) or ALT2 (Ab 11010 or Ab 11008 at $0.1 \mu \mathrm{g} / \mathrm{ml}$ dilution). The blots incubated with the primary antibody were probed with the corresponding secondary IgG antibody (Pierce 31464, 1:50,000 dilution), conjugated to horseradish peroxidase. The ECL and ECL Advance Western blot detection system (Amersham, UK) were used according to the manufacturer's instructions and emitted light was detected in a Fujifilm LAS 3000 Mini (Science Imaging Scandinavia, Nacka, Sweden). The resulting bands were confirmed by comparing the size of the protein in the cell extract with known molecular markers (MagicMark XP, Invitrogen). In addition, recombinant ALT1 and 2 proteins were used as positive controls for all Western blots.

Enzyme kinetics and stability. Pyruvate, NADH, NADPH, LDH, GDH, alanine, 2-oxoglutarate and glutamate ammonium salt were purchased from Sigma and used without further purification. Enzyme activities were determined in coupled enzyme reactions by employing indicator reactions using LDH (forward reaction) and GDH (reverse reaction) to react with the formed products pyruvate and 2-oxoglutarate, respectively. Both indicator reactions convert $\mathrm{NAD}(\mathrm{P}) \mathrm{H}$ to $\mathrm{NAD}(\mathrm{P})^{+}$. Kinetic constants for alanine were determined with serial dilutions of alanine supplemented with $30 \mathrm{mM}$ 2-oxoglutarate, $0.2 \mathrm{mg} / \mathrm{ml}$ $\mathrm{NADH},>3 \mathrm{U} / \mathrm{ml} \mathrm{LDH}$ in $0.1 \mathrm{M}$ phosphate buffer $\mathrm{pH}$ 7.3. Kinetic constants for 2-oxoglutarate were determined with serial dilutions of 2-oxoglutarate supplemented with $300 \mathrm{mM}$ alanine, $0.2 \mathrm{mg} / \mathrm{ml} \mathrm{NADH},>3 \mathrm{U} / \mathrm{ml} \mathrm{LDH}$ in $0.1 \mathrm{M}$ phosphate buffer $\mathrm{pH}$ 7.3. Kinetic constants for pyruvate were determined with serial dilutions of pyruvate supplemented with $1 \mathrm{M}$ glutamate, $0.2 \mathrm{mg} / \mathrm{ml} \mathrm{NADPH},>7.5 \mathrm{U} / \mathrm{ml} \mathrm{GDH}$ in $0.1 \mathrm{M}$ phosphate buffer $\mathrm{pH}$ 7.3. Kinetic constants for glutamate were determined with serial dilutions of glutamate supplemented with $5 \mathrm{mM}$ pyruvate, $0.2 \mathrm{mg} / \mathrm{ml} \mathrm{NADPH},>7.5 \mathrm{U} / \mathrm{ml} \mathrm{GDH}$ in $0.1 \mathrm{M}$ phosphate buffer $\mathrm{pH}$ 7.3. Enzyme activity was measured in a 96-well microtiter plate following the absorbance change at $340 \mathrm{~nm}$ using a spectraMAX (Molecular Devices). A molar absorptivity of $6,220 \mathrm{M}^{-1} \mathrm{~cm}^{-1}$ was used for NAD(P)H and the length was determined as $0.4 \mathrm{~cm}$ through calibration with NADH standards. $k_{\text {cat }}$ Values were based on a molecular mass of 54 and $58 \mathrm{kDa}$ for ALT1 and 2, respectively. A weight non-linear-regression analysis program was used to calculate the kinetic constants (XLfit4 Excel Add-in Version 4.2.2). In order to determine the purity of various enzyme preparations, protein solutions were analyzed by SDS-PAGE. The gel was stained with Syrpo Ruby total protein stain and scanned in Ettan DIGE Imager (GE Healthcare) according to standard procedures. Image analysis was then performed and the 
integrated intensity volume from the band corresponding to the ALT enzyme was then related to the total integrated intensity volume corresponding to the whole sample (Fujifilm LAS 3000 Mini). For stability experiments with recombinant proteins, a commercial human serum was used (Sigma-Aldrich, \#H4522, Lot.nr 027K0432). The ALT activity in this serum was $10 \mathrm{U} / 1$.

Isolation of mitochondria from cell lysates. Human primary hepatocytes or cultured skeletal muscle cells (Hs94.T) (1-2x107) were used for separating subcellular fractions; cytosol, endoplasmatic reticulum (ER)/plasma membrane and mitochondria fractions. The separation was performed according to Qproteome Mitocondria Isolation Kit (Qiagen). The cytosol fraction was concentrated by acetone precipitation before SDS-PAGE analysis. Protein concentrations were determined with Bradford protein assay (BioRad). Antibody against cytochrome C (\#21465, Abcam, Cambridge, UK) was used on Western blot analysis to test the degree of purity of the mitochondrial fractionation.

Immunohistochemistry. Tissue microarray slides (normal organs in duplicates slide type \#AA9) were purchased from Super Biochips, South Korea. The slides contained $2 \mathrm{~mm}$ spots of 30 human organs in duplicates from $\sim 60$ separate individuals. The samples were taken from both male and female patients aged from 17 to 90 years. According to the manufacturer, the tissues are sectioned at $4 \mu \mathrm{m}$ and fixed in formalin and processed into wax blocks. Immunohistochemical staining for the detection of ALT2 (Ab.11008), and human cytochrome oxidase IV subunit I (Molecular Probes A-6403) on tissue sections was performed on the staining module Discovery XT (Ventana ${ }^{\circledR}$ Medical Systems Inc, USA). Ventana Medical Systems Inc, USA, supplied all solutions for deparaffinization, pre-treatment, detection, counterstaining and rinsing steps. The slides were deparaffinized and rehydrated in the machine.

Immunohistochemistry protocol for detection of ALT2 was performed as follows. The sections were pre-treated for antigen retrieval for $4 \mathrm{~min}$ in Protease 1 . The primary antibody antiALT2, diluted in $40 \mu \mathrm{g} / \mathrm{ml} \mathrm{PBS}$, was incubated on the sections at $37^{\circ} \mathrm{C}$ for $32 \mathrm{~min}$, followed by $16 \mathrm{~min}$ incubation with the prediluted secondary antibody, UltraMap ${ }^{\mathrm{TM}}$ anti $\mathrm{Rb}$ AP (Ventana) at RT. The immunoreactions were visualized with the UltraMAP ${ }^{\text {тм }}$ blue kit, which includes development with NBT-BCIP, for $32 \mathrm{~min}$. The sections were washed thoroughly in reaction buffer between each step (minimum $3 \times 3 \mathrm{~min}$ ). All sections were counterstained with nuclear fast red for $4 \mathrm{~min}$. Dehydration in rising concentration of ethanol, clearing in xylene and mounting with Cytoseal ${ }^{\mathrm{TM}}$ XYL (Richard-Allan Scientific, USA) were done manually.

Immunohistochemistry protocol for detection of cytochrome oxidase IV subunit I was performed as follows. The sections were pre-treated for antigen retrieval at $98^{\circ} \mathrm{C}$ for $40 \mathrm{~min}$ in Cell Conditioning 1, which is a Tris/borate/EDTA buffer $\mathrm{pH}$ 8. The primary antibody was diluted to $10 \mu \mathrm{g} / \mathrm{ml}$ in PBS and incubated on the sections for $3 \mathrm{~h}$ at $37^{\circ} \mathrm{C}$. Next, the biotinylated secondary antibody was applied. Goat anti-mouse immunoglobulin (prod no E0433 Dako A/S, Denmark, diluted 1/200 in Antibody Diluent, Ventana Medical System Inc.) with $5 \%$ normal goat serum (Dako A/S), were incubated on the sections for $28 \mathrm{~min}$ at RT. The immunoreactions were visualized with the DAB-MAP ${ }^{\mathrm{TM}}$ kit. The DAB-MAP kit includes blocking of endogenous peroxidase with $\mathrm{H}_{2} \mathrm{O}_{2}$ and detection with a streptavidin-biotin complex conjugated with horseradish peroxidase and development with the chromogene 3,3'-diaminobenzidin (DAB). The sections were washed thoroughly in reaction buffer between each step (minimum $3 \times 3 \mathrm{~min}$ ). All sections were counterstained with haematoxylin for $4 \mathrm{~min}$ and blued in Bluing Reagent for $4 \mathrm{~min}$. Dehydration in rising concentration of ethanol, clearing in xylene and mounting with Cytoseal XYL were done manually. For every staining method and occasion, one slide was stained without primary antibody (only PBS in the primary antibody step) to serve as negative control.

Measurement of relative levels of ALT1 and 2 in serum and plasma. Informed consent was obtained from volunteers prior to any blood sampling. Blood was taken from 11 healthy volunteers in either serum or heparin tubes for serum and plasma preparation respectively. The blood withdrawal to prepare either serum or plasma did not occur on the same day. Plasma preparation was performed on ice or at $4^{\circ} \mathrm{C}$, while serum preparation was performed at room temperature $\left(22^{\circ} \mathrm{C}\right)$. Both serum and plasma were stored at $-80^{\circ} \mathrm{C}$ before further use. Serum or plasma $(100 \mu \mathrm{l})$ was co-incubated with ALT antibodies, ALT1 (Ab.10995, $1.0 \mu \mathrm{g}$ ) and ALT2 (Ab.11008, $1.0 \mu \mathrm{g})$ end-over-end $2 \mathrm{~h}$ at $4^{\circ} \mathrm{C}$. Dynabeads $(50 \mu \mathrm{l})(\mathrm{M}-280$ Sheep anti-rabbit, Dynal, Invitrogen) were added to the serum or plasma and incubated for an additional $1 \mathrm{~h}$, with end-overend mixing. The Dynabeads were removed using a magnet and the remaining solution was used for ALT activity measurements (acc. IFCC, ALTLP: ACN 684, Cobas, Roche).

Immunoprecipitation of ALT1 and 2 in human plasma. Dynabeads (1 ml) (M-280 Sheep anti-rabbit, Dynal, Invitrogen) were washed three times with PBS using the magnetic separation and finally resuspended in $1 \mathrm{ml}$ PBS. ALT2 antibody $(100 \mu \mathrm{g})$ (Ab. 11008) or $100 \mu \mathrm{g}$ ALT1 antibody (Ab.10995) was added to the dynabead solution in PBS and was allowed to incubate for $1 \mathrm{~h}$ end-over-end at $4^{\circ} \mathrm{C}$. The beads were washed five times with PBS after which crosslinking of the ALT Ig antibodies to the beads occurred using $1 \mathrm{ml} 0.2 \mathrm{M}$ triethanolamine $\mathrm{pH}$ 8.2. The beads were washed twice with triethanolamine and resuspended in $1 \mathrm{ml} 20 \mathrm{mM}$ dimetylpipelimidate dihydrochloride (DMP) in $0.2 \mathrm{M}$ triethanolamine $\mathrm{pH}$ 8.2. Further incubation for $30 \mathrm{~min}$ at $20^{\circ} \mathrm{C}$ was performed before separation with magnet. The reaction was stopped using $1 \mathrm{ml} 50 \mathrm{mM}$ TRIS pH 7.5 and incubated for $15 \mathrm{~min}$. Washing was performed two times with $0.1 \mathrm{M}$ glycine $\mathrm{pH} 2.5$ and three times with $\mathrm{PBS} / 0.1 \%$ BSA. Human plasma $(2 \mathrm{ml})$ was added, and incubated for $1 \mathrm{~h}$ at $4{ }^{\circ} \mathrm{C}$ endover-end. Beads were separated and the supernatant was removed. The beads were washed five times with PBS before elution of ALT antigen from the antibodies took place. Three elutes were saved, $100 \mu 10.1 \mathrm{M}$ glycine $\mathrm{pH} 2.5$ (Elute 1, E1), $100 \mu 12$ M Urea (Elute 2, E2) or $100 \mu 11$ x SDS buffer (Elute 3, E3). 2 x SDS-buffer were added to the E1 and 2 elutes and all elutes were boiled for $5 \mathrm{~min}$ prior to being loaded on a SDS-PAGE gel for Western blot analysis. 
Table I. Kinetic constants for recombinant human ALT1, ALT2 and ALT2_2.

\begin{tabular}{|c|c|c|c|c|c|c|c|c|c|c|c|c|}
\hline \multirow{3}{*}{$\begin{array}{l}\text { Substrate } \\
\text { Enzyme }\end{array}$} & \multicolumn{6}{|c|}{ Forward reaction } & \multicolumn{6}{|c|}{ Reverse reaction } \\
\hline & \multicolumn{3}{|c|}{ Alanine } & \multicolumn{3}{|c|}{ 2-oxoglutarate } & \multicolumn{3}{|c|}{ Pyruvate } & \multicolumn{3}{|c|}{ Glutamate } \\
\hline & $\begin{array}{c}\mathrm{K}_{\mathrm{m}} \\
(\mathrm{mM})\end{array}$ & $\begin{array}{c}\mathrm{k}_{\mathrm{cat}} \\
\mathrm{min}^{-1}\end{array}$ & $\begin{array}{c}\mathrm{k}_{\mathrm{cat}} / \mathrm{K}_{\mathrm{m}} \\
\mathrm{min}^{-1} / \mathrm{mM}\end{array}$ & $\begin{array}{c}\mathrm{K}_{\mathrm{m}} \\
\mathrm{mM}\end{array}$ & $\begin{array}{c}\mathrm{k}_{\mathrm{cat}} \\
\min ^{-1}\end{array}$ & $\begin{array}{c}\mathrm{k}_{\mathrm{cat}} / \mathrm{K}_{\mathrm{m}} \\
\mathrm{min}^{-1} / \mathrm{mM}\end{array}$ & $\begin{array}{c}\mathrm{K}_{\mathrm{m}} \\
\mathrm{mM}\end{array}$ & $\begin{array}{c}\mathrm{k}_{\mathrm{cat}} \\
\mathrm{min}^{-1}\end{array}$ & $\begin{array}{c}\mathrm{k}_{\mathrm{cat}} / \mathrm{K}_{\mathrm{m}} \\
\mathrm{min}^{-1} / \mathrm{mM}\end{array}$ & $\begin{array}{c}\mathrm{K}_{\mathrm{m}} \\
\mathrm{mM}\end{array}$ & $\underset{\mathrm{min}^{-1}}{\mathrm{k}_{\mathrm{cat}}}$ & $\begin{array}{c}\mathrm{k}_{\mathrm{cat}} / \mathrm{K}_{\mathrm{m}} \\
\mathrm{min}^{-1} / \mathrm{mM}\end{array}$ \\
\hline rhALT1 & 70 & 16000 & 230 & 0.4 & 10500 & 24400 & 1.0 & 10700 & 10900 & 6.7 & 8000 & 1200 \\
\hline rhALT2 & 15 & 14100 & 940 & 1.2 & 15100 & 12600 & 0.3 & 5200 & 17300 & 30 & 9300 & 310 \\
\hline rhALT2_2 & & n.a. ${ }^{\mathrm{a}}$ & & & n.a. & & & n.a. & & & n.a. & \\
\hline $\mathrm{hALT}^{\mathrm{c}}$ & 21 & $-\mathrm{b}$ & - & 0.22 & - & - & - & - & - & - & - & - \\
\hline hALT2c (mit) & 5.1 & - & - & 0.19 & - & - & - & - & - & - & - & - \\
\hline
\end{tabular}

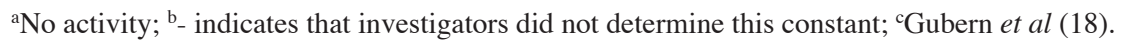

\section{Results}

Enzymatic activity of alanine aminotransferases. Visualisation of enriched recombinant ALT1, 2 and 2_2 from bacteria lysates showed about equal amount of ALT1 and 2 with $25 \%$ purity for both ALT1 and 2. The ALT2_2 preparation had the highest purity of the recombinant proteins $(>80 \%)$. Using the standard clinical settings for the determination of ALT activity levels (IFCC standard, ALTLP: ACN 684, Cobas, Roche), the recombinant proteins ALT1 and 2 yielded 80,500 and 81,500 U/1 per mg total protein respectively (at $\mathrm{pH} 7.6$ ) from this preparation. Under these conditions, recombinant ALT2_2 did not possess any enzymatic activity at all. As a negative control, enzyme preparations were also performed from cells transformed with a vector construct containing eGFP. ALT activity measurement from this preparation yielded no enzymatic activity. In order to characterize the kinetic activity of the ALT1 and ALT2 enzymes, the steady state kinetic constants $\mathrm{K}_{\mathrm{m}}$ and $\mathrm{k}_{\text {cat }}$ were determined for alanine and 2-oxoglutarate (forward reaction), as well for pyruvate and glutamate (reverse reaction; Table I). Again, ALT2_2 did not show activity for any of these substrates regardless of concentration. Values of $\mathrm{k}_{\text {cat }}$ were roughly in the same order of magnitude for ALT1 and ALT2 enzymes and for both forward and reverse reactions, i.e., 5,000-15,000 $\mathrm{min}^{-1}$. For alanine (forward reaction), ALT1 showed a somewhat higher $\mathrm{K}_{\mathrm{m}}$ than ALT2 (70 mM versus $15 \mathrm{mM}$ respectively), whilst for 2-oxoglutarate ALT1 showed a 3-fold lower $\mathrm{K}_{\mathrm{m}}$ than ALT2. For the reverse reaction, ALT1 had a higher $\mathrm{K}_{\mathrm{m}}$ for pyruvate $(1 \mathrm{mM})$ and a lower $\mathrm{K}_{\mathrm{m}}$ for glutamate $(6.7 \mathrm{mM})$, compared to ALT2, which exhibited a $\mathrm{K}_{\mathrm{m}}$ of 0.3 and $30 \mathrm{mM}$ for pyruvate and glutamate, respectively. Naturally, in accordance with these $\mathrm{K}_{\mathrm{m}}$ determinations, $\mathrm{k}_{\mathrm{cal}} / \mathrm{K}_{\mathrm{m}}$ values for both the enzymes are consequently highest for 2-oxoglutarate and pyruvate.

Stability of recombinant ALT1 and ALT 2 by temperature. In order to test the effect of different temperatures on the stability of enzymatic activity of catalytically active ALT1 and 2, $3 \mu \mathrm{g}$ recombinant protein was exposed to $4^{\circ} \mathrm{C}$, room temperature $\left(22^{\circ} \mathrm{C}\right)$ and body temperature $\left(37^{\circ} \mathrm{C}\right)$ for different time points up to $24 \mathrm{~h}$ in the presence of a $90 \%$-serum solution (Sigma-
Aldrich). ALT1 was stable under all temperature conditions, and lost only $20 \%$ activity at $37^{\circ} \mathrm{C}$ for $24 \mathrm{~h}$ (Fig. 1a). The ALT2 protein, on the other hand, was very unstable and lost its enzymatic activities exponentially at $37^{\circ} \mathrm{C}$ (Fig. 1a). After $24 \mathrm{~h}$, $<1 \%$ activity was left. However, at $22^{\circ} \mathrm{C}$, ALT2, lost $~ 50 \%$ activity after $24 \mathrm{~h}$ (Fig. 1b), but at $4^{\circ} \mathrm{C}$, the ALT2 protein lost only $25 \%$ activity in $24 \mathrm{~h}$ (Fig. 1c). Storage of recombinant ALT1 and 2 in the freezer was also tested. ALT1 protein did not lose any enzymatic capacity in -20 or $-80^{\circ} \mathrm{C}$ storage for one week. ALT2 protein, on the other hand, lost $13 \%$ enzymatic activity at $-20^{\circ} \mathrm{C}$, but remained stable at $-80^{\circ} \mathrm{C}$ for the one week studied (data not shown).

In a first attempt to investigate why ALT2 enzymatic capacity is lost, recombinant protein was incubated in glycerol buffer (ALT buffer) consisting of PBS, BSA and 25\% glycerol instead of human serum. ALT1 and especially ALT2 were much more stable in this glycerol buffer. Addition of alanine (100 mM) increased the stability of ALT2 protein further, whilst a cocktail of protease inhibitors had no effect (data not shown). Furthermore, ALT2 was more stable in a plasma environment than in a serum environment (Fig. 1d).

Validation of specific ALT2 antibody and expression in liver extract. In order to study the catalytically active ALT2 isoform and distinguish it from the catalytically inactive ALT2_2, validation of the novel N-terminal ALT antibody (11008) was performed. Recombinant ALT2 and 2_2 protein together with human heart tissue lysate were loaded onto an SDS-page gel and transferred to a membrane for Western blot detection. Antibody 11010, directed against the C-terminal, recognizes both ALT2 isoforms and antibody 11008 recognizes only ALT2. As seen in Fig. 2, the 11010 antibody detected both ALT2 (58 kDa + His-tag) and ALT2_2 (47 kDa + His-tag) and a specific protein in heart lysate at $47 \mathrm{kDa}$. However, the antibody 11008 detected only the catalytically active ALT2. To study if ALT2 is detected in human liver, we loaded human liver extract on SDS-PAGE gels and used four different ALT2 antibodies (11008, 11010 and two commercial ALT2 antibodies). As seen in Fig. 3, ALT2 was not detected in the human liver extract using any of these four antibodies. In contrast, the ALT1 antibody gave an intense band at the predicted molecular weight. In addition, we also tested another 
a

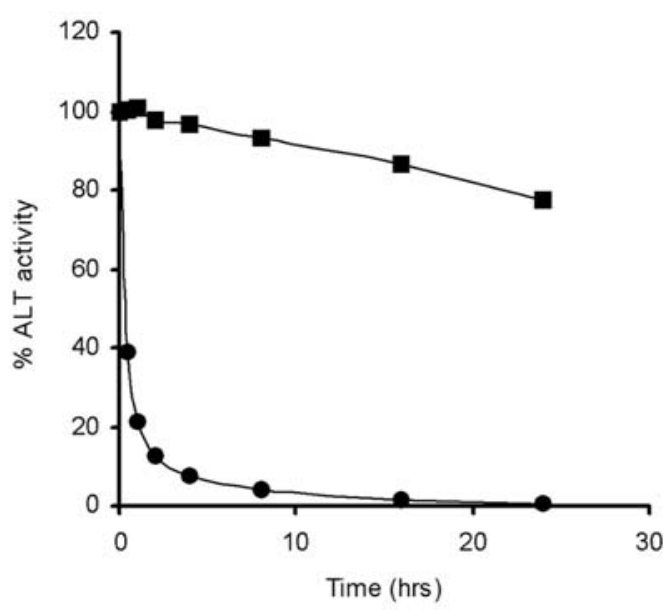

c

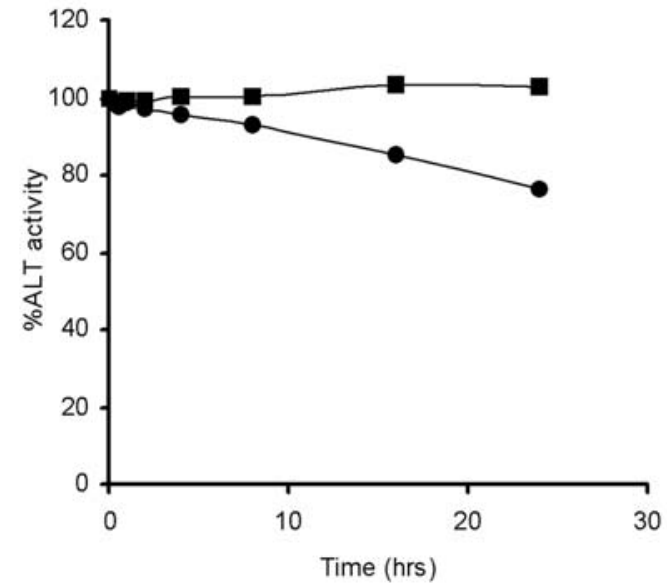

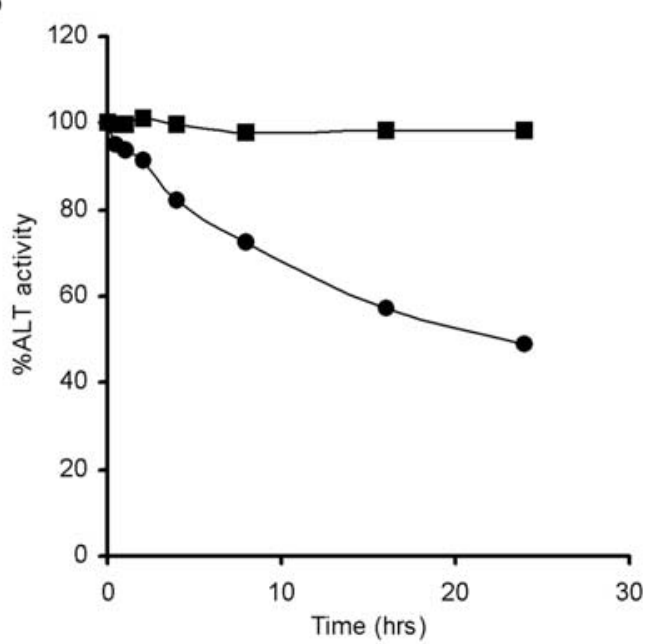

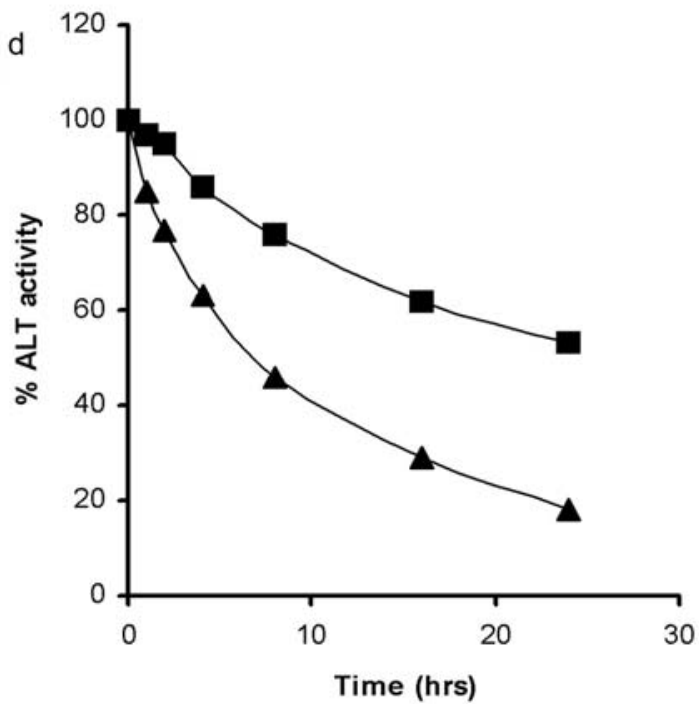

Figure 1. Stability of enzymatic activity of recombinant ALT1 and 2 proteins in a serum environment by time (h) at (a) $37^{\circ} \mathrm{C}$ (b) $22^{\circ} \mathrm{C}$ (c) $4^{\circ} \mathrm{C}$. Black squares represent ALT1 recombinant protein, black circles represent ALT2 recombinant protein. (d) Stability of recombinant ALT2 (22 $\left.{ }^{\circ} \mathrm{C}\right)$ in a serum (black triangles) or plasma (black squares) environment.

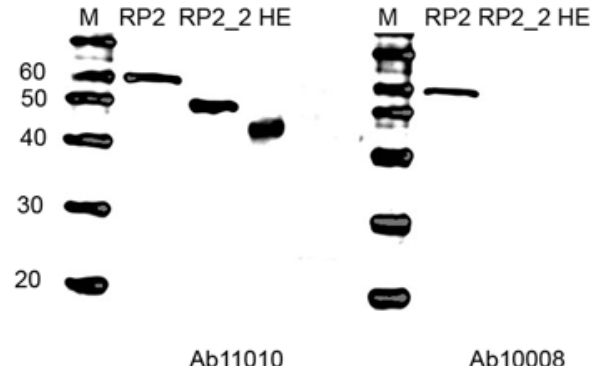

Figure 2. Western blotting of recombinant proteins. RP2 represents ALT2 recombinant protein and RP2 22 represents ALT2_2 recombinant protein. HE represents human heart extract $(20 \mu \mathrm{g})$ using two different ALT2 antibodies (left panel Ab.11010 and right panel 11008) for detection. The molecular marker (M) with known molecular sizes are marked in $\mathrm{kDa}$ values.

antibody (B-actin) on the transferred liver extract and found a clear band at the correct size $(47 \mathrm{kDa})$ indicating the robustness of the liver extract (data not shown).

Subcellular localization of ALT in human hepatocytes and skeletal muscle cells. Subcellular localization of catalytic

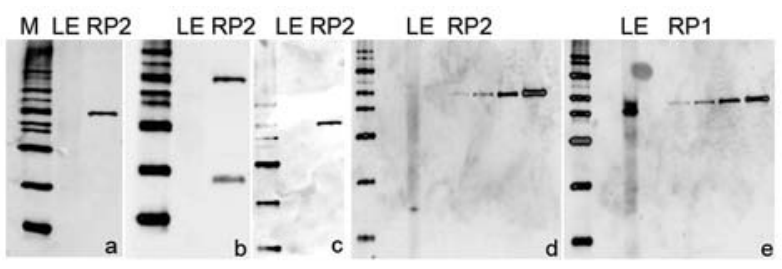

Figure 3. Western blotting of human liver extract (LE, $20 \mu \mathrm{g}$ ) using ALT2 antibodies (a) commercial sc-46352 (b) commercial sc-46350 (c) Ab.11008 (d) Ab 11010 with ALT2 recombinant protein loaded at 25, 50, 100 and $200 \mathrm{ng}$. (e) Western blotting of human liver extract (LE, $20 \mu \mathrm{g}$ ) using ALT1 antibody (10995) with ALT1 recombinant protein loaded at 25, 50, 100 and $200 \mathrm{ng}$. The molecular marker (M) with known molecular sizes are shown in Fig. 2.

forms of ALT1 and 2 were studied in human primary hepatocytes and in the skeletal muscle cell line, Hs94.T. After separating cytosol, ER/plasma membrane and mitochondrial fractions, cell extracts were analysed by Western blotting and the degree of purification of the cellular components was tested using an antibody for the mitochondrial cytochrome C. As shown in Fig. 4a, cytochrome C (10 kDa) appeared mainly in 

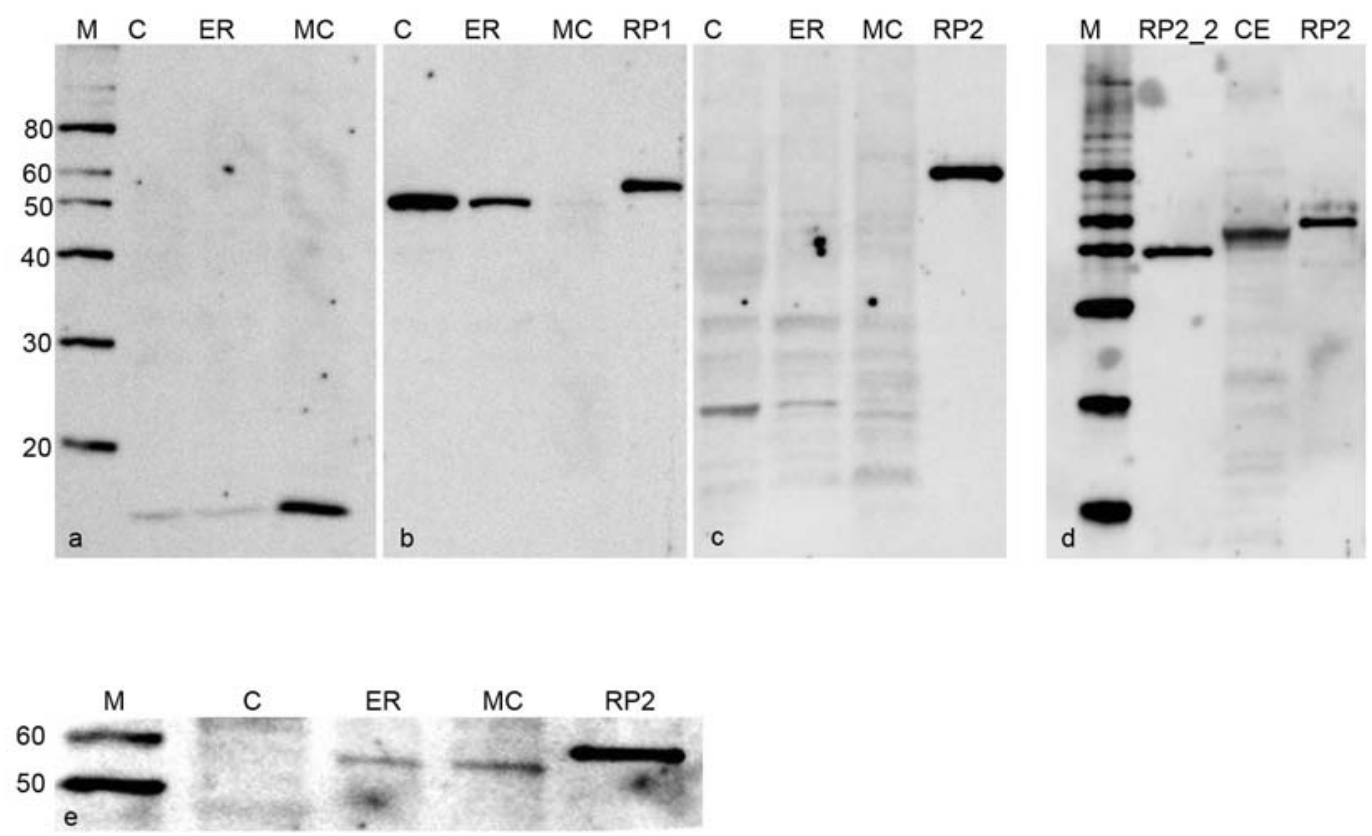

Figure 4. Western blotting of subcellular fractions from primary human hepatocytes. (a) Strong detection of cytochrome C in mitochondria (MC), and weak detection in endoplasmatic reticulumn (ER) and cytosol (C). (b) Detection of ALT1 using 10995 Ab. in cytosol and endoplasmatic reticulumn. No detection in MC. RP1 represent ALT1 recombinant protein loaded at $200 \mathrm{ng}$. (c) No detection of ALT2 using $11010 \mathrm{Ab}$. in cytosol, ER or MC. RP2 represents ALT2 recombinant protein, loaded at $200 \mathrm{ng}$; $\mathrm{M}$ represents the molecular marker in $\mathrm{kDa}$ in a, d, and e. (d) Western blotting of cell extract (CE, $20 \mu \mathrm{g})$ from cultured skeletal muscle cells Hs94.T with detection of a band corresponding to the size of endogenous ALT2 (58 kDa). RP2_2 represents ALT2_2 recombinant protein loaded at $200 \mathrm{ng}$. RP2 represents ALT2 recombinant protein loaded at $200 \mathrm{ng}$. (e) Detection of a band corresponding to the size of endogenous ALT2 $(58 \mathrm{kDa})$ in subcellular fraction of MC and ER in cultured skeletal muscle cells Hs94.T. No band detected in cytosolic fraction.

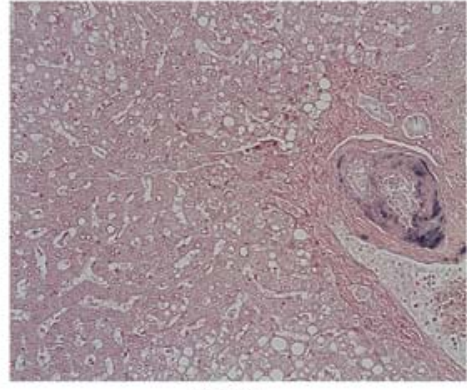

ALT2

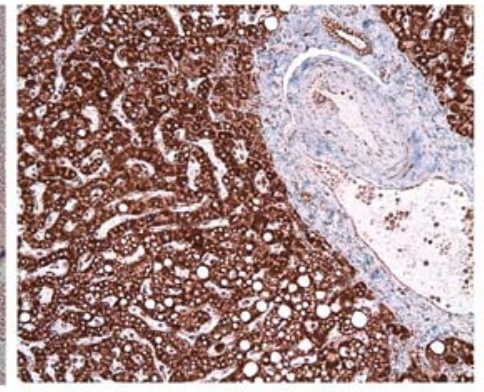

COXIV

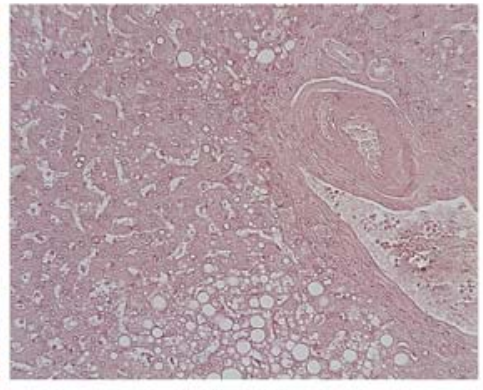

Control

Figure 5. Immunohistochemical localization of ALT2 and Cytochrome Oxidase IV Subunit I in human liver. Positive staining for ALT2 (blue) in smooth muscle cells in the wall of terminal portal venules. Cytochrome Oxidase IV Subunit I is visualised as brown staining in hepatocytes. No signal is detected in controls where primary antibody is omitted. Lens x10 used for all liver sections.

the mitochondrial fraction with a very weak band present in ER and cytosol. The ALT1 protein was present in high amounts in the cytosol of hepatocytes, and to a lesser extent in the ER. The mitochondrial fraction was absent of any ALT1 (Fig. 4b). Similarly, ALT2 was absent in all subcellular fractions in primary hepatocytes, thus localization was not studied in these cells (Fig. 4c). In order to study the localization of catalytic ALT2, skeletal muscle cells were lysed and Western blotting performed. In Fig. 4d, a band is clearly visible at the predicted size $(58 \mathrm{kDa})$ in this cell extract, between the recombinant His-tagged ALT2 (62 kDa) and ALT2_2 (51 kDa). Further, these cells were also used for analysis of subcellular fractions, and ALT2 bands at the predicted size were visible in the ER and mitochondrial fractions, but not in the cytosolic fraction (Fig. 4e).
Detection of ALT2 in human tissues by immunohistochemistry. In line with previous observations from cultured hepatocytes, ALT2 expression was not detected in formalin fixed, paraffin embedded sections of human liver. Smooth muscle cells in the walls of terminal portal venules were the only ALT2 expressing cell type in the liver (Fig. 5). The mitochondrial marker, cytochrome oxidase IV subunit I, was present in high amounts in the liver parenchyma and was mainly detected in hepatocytes (Fig. 5). Catalytic ALT2 was also expressed in the cardiac myocytes and showed a comparable staining pattern to that of cytochrome oxidase IV subunit I (Fig. 6a). In cross sections of skeletal muscle fibres and pancreas, ALT2 distribution was again comparable to cytochrome oxidase IV subunit I, which indicates that ALT2 in these tissues localizes to the mitochondrial compartment (Fig. 6b and c), further supporting 
a

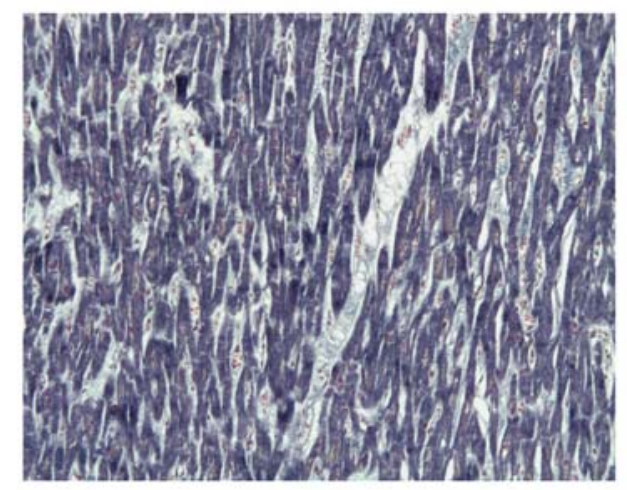

b

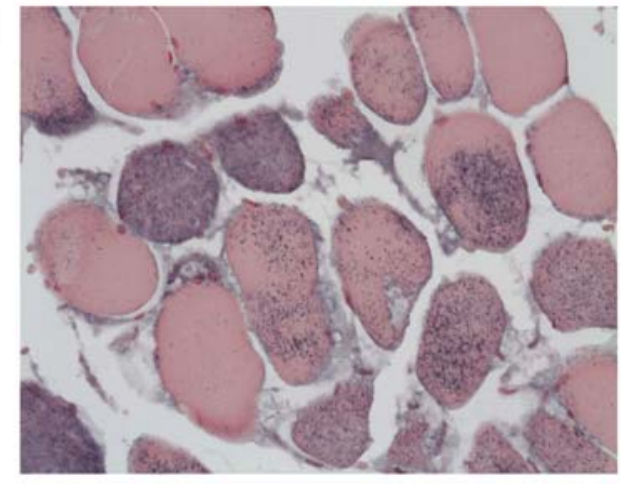

C

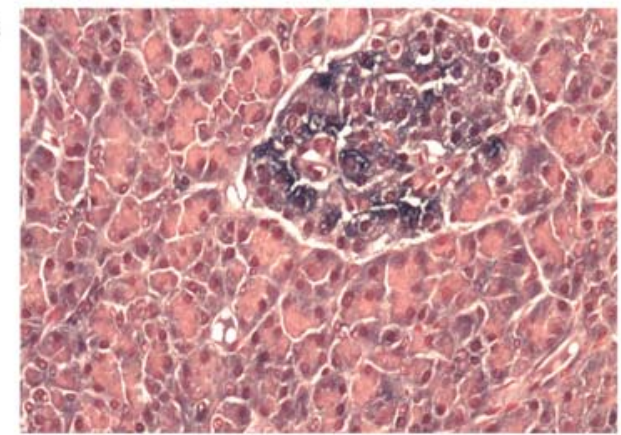

d

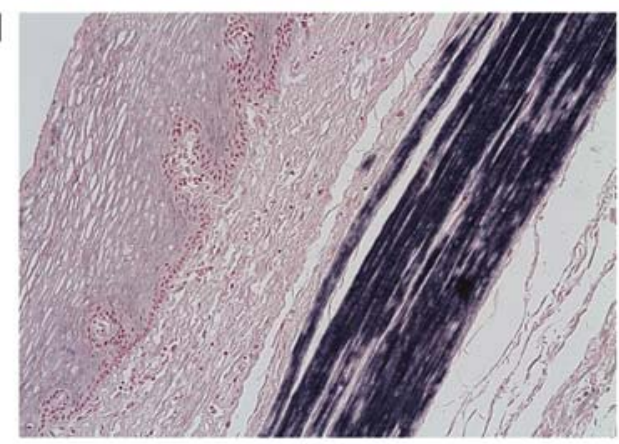

ALT2
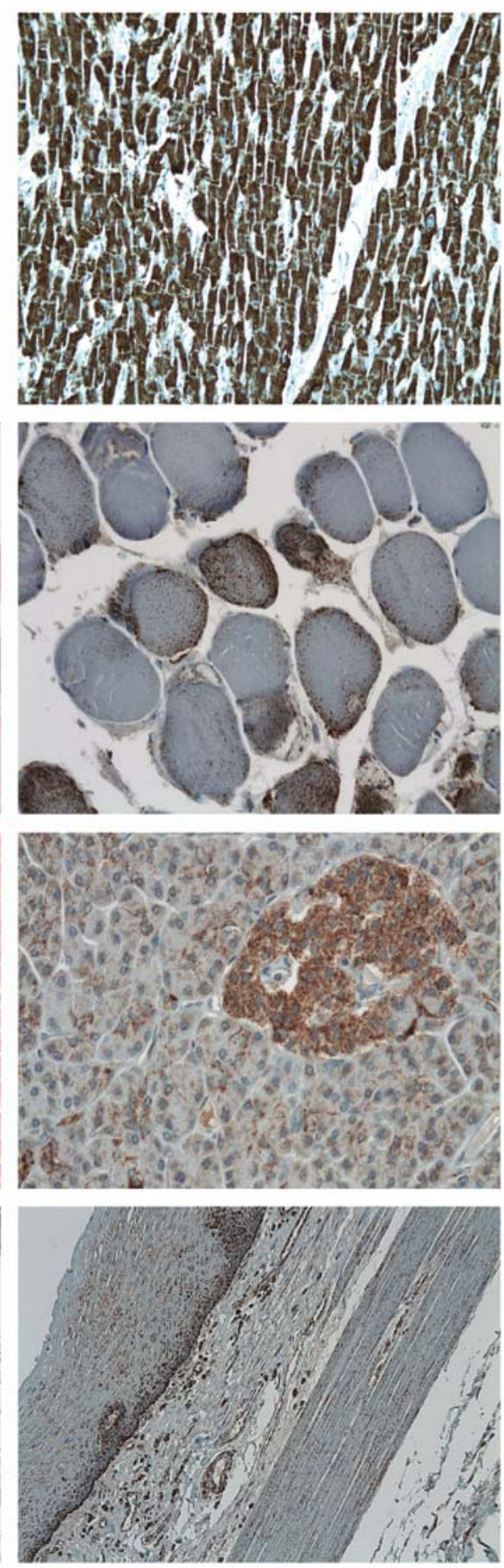

COX IV

Figure 6. Immunohistochemical localization of ALT2 (blue) and cytochrome oxidase IVs Subunit I (brown). (a) Heart, ALT2 and cytochrome oxidase IV subunit I positive stainings in cardiac muscle cells. Lens, x10. (b) Skeletal muscle fibers, similar staining for both ALT2 and cytochrome oxidase IV subunit I. Lens x40. (c) Pancreas, islets of Langerhans show strong positive staining for ALT2 and Cytochrome Oxidase IV Subunit I. Pancreatic epithelial cells shows weaker staining. Lens x20. (d) Esophagus, smooth muscle layer shows a strong expression of ALT2. Lens x10.

the in vitro finding in cultured skeletal muscle cells (Fig. 4e). In the esophagus, a strong expression of ALT2 was detected in the striated and smooth muscle layer. Cytochrome oxidase IV subunit I was also found in these layers, but with a lower expression (Fig. 6d).

Immunoprecipitation of recombinant proteins with ALT1 and 2 antibodies. The ALT antibodies work well under denaturating conditions (i.e., Western blot analysis). However, for immunoprecipitation (IP) to function correctly on ALT in plasma or serum, the antibodies also need to bind under native conditions. In order to test this, recombinant ALT1 and 2 were prepared under native conditions and ALT activity was measured before the preparations were used in the experiments. Different antibody concentrations $(0.5-20 \mu \mathrm{g})$ were incubated with recombinant ALT1 and 2 proteins in a human serum 
environment and IP was performed using the anti-ALT antibodies. ALT1 antibody (1 $\mu \mathrm{g}$, with $50 \mu 1$ Dynabeads) precipitated $100 \%$ of ALT activity from the solution containing ALT1 recombinant protein with an activity of $106 \mathrm{U} / \mathrm{l}$. In a mixture of 50\% recombinant ALT1 and 2, total activity was $130 \mathrm{U} / 1$ in which ALT1 theoretically contributed $\sim 53 \mathrm{U} / 1$ and ALT2 77 U/l. After IP with the ALT1 antibody $(1 \mu \mathrm{g}) 69 \mathrm{U} / 1$ activity remained, indicating that the ALT1 antibody pulled down $>100 \%$ (115\%) of the theoretical ALT1 contributing to the activity in the solution. Conversely, to study IP using ALT2 antibodies (Ab. 11010 and 11008), recombinant ALT2 protein with an activity of $165 \mathrm{U} / \mathrm{l}$ was used. Ab. 11010 precipitated $\sim 8-15 \%$ of the ALT2 activity when titrating the antibody concentration (0.25-20 $\mu \mathrm{g})$. However, antibody 11008 precipitated ALT2, in a dose-dependent fashion. Applying $1 \mu \mathrm{g}$ antibody precipitated $25 \%, 10 \mu \mathrm{g}$ antibody $55 \%$ and $20 \mu \mathrm{g}$ antibody $69 \%$.

Detection of ALT2 in human serum and plasma. In our previous work we found ALT1 was responsible for ALT activity in human serum of 8 healthy individuals tested (6). However, based upon the stability result of ALT2 in plasma in this work, we decided to test IP on plasma samples taken in Li-heparin tubes. To ensure highest possible integrity of the blood/plasma, the preparations were performed using cold tubes stored on ice and centrifugation took place at $4^{\circ} \mathrm{C}$. Applying the IP protocol on these plasma samples, a lower percentage precipitation of ALT activity using ALT1 antibody was observed with an average of $93 \%$ (SD, 3.9) precipitation. While ALT activity from serum samples was precipitated to $99 \%$ (SD, 3.0, $\mathrm{p}<0.001$ compared to plasma samples) using the ALT1 antibody.

In order to detect ALT1 and 2 structurally, we first attempted direct detection by loading $\operatorname{IgG}$ and albumin depleted serum on a gel and performed Western blotting. Using this approach we did not detect ALT1 or 2 in normal serum/plasma samples. However, an ALT1 band, but not ALT2, was seen in a plasma sample containing high ALT activity $>200 \mathrm{U} / 1$ (data not shown). Instead, we performed IP using the ALT antibodies on plasma and analysed the elutes from the IP by Western blot analysis. In Fig. 7a, the band corresponding to ALT1 in size was easily detected from ALT1 IP of human plasma. To detect ALT2 in plasma, IP was performed using antibody 11008 , and dual detection using ALT2 antibody (11010) on Western blot served as an extra control. A band at the predicted molecular weight for ALT2 was present, in IP elute 1 (glycine) and elute 2 (urea), but not in elute 3 (SDS) (Fig. 7b).

\section{Discussion}

Serum alanine aminotransferase (ALT) activity is used in clinics and in safety assessment of pharmaceuticals as a surrogate marker of liver injury. The cloning of ALT2 and the demonstration of differential tissue expression at mRNA levels for GPT1 and $2(5,15)$, led to the hypothesis that increased serum ALT levels are caused by a specific leakage of ALT2 from other organs than the liver (5). Indeed, ALT activity was found in other organs, mostly in the kidneys (50\% of liver activity/g tissue), heart (20\%), skeletal muscle (10-20\%) and pancreas $(16,17)$. The basal levels of ALT in blood are, in

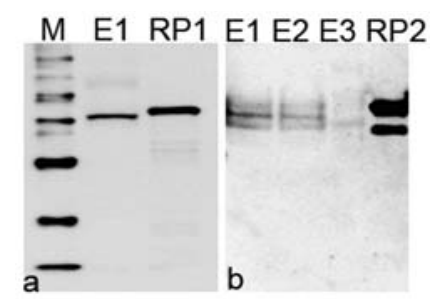

Figure 7. Immunoprecipitation of (a) ALT1 or (b) ALT2 from human plasma sample. Detection of a band corresponding to ALT1 (54 kDa) in E1 represents Elute 1 using $0.1 \mathrm{M}$ glycine $\mathrm{pH} 2.5$, E2 represents Elute 2 using $2 \mathrm{M}$ Urea and E3 represents Elute 3 using 1x SDS buffer. RP1 is an ALT1 recombinant protein loaded at $200 \mathrm{ng}$ and RP2 is ALT2 recombinant protein loaded at $200 \mathrm{ng}$.

part, a result of a poorly understood process involving hepatocytes and possibly turnover in other tissues. In connection with liver injury, and according to the currently accepted view, ALT and other enzymes leak from necrotic cells and reach the blood. The current ALT assay measures total catalytic activity in plasma or serum, which is the combined activity of ALT1 and 2. In our earlier study, using novel ALT1 and 2 antibodies, we extended previous work from transcriptional levels and showed that there is a differential tissue expression of ALT isoforms, yet, the dominant form present in normal human serums is ALT1 (6). The ALT1 protein is mainly expressed in the liver and kidney. ALT2 proteins are mainly expressed in the pancreas, brain, adrenal gland, skeletal muscle and heart. However, analysing heart and muscle extracts more closely with Western blotting, we detected only high expression of a splice variant of ALT2 (ALT2_2). At that time, it was not known if ALT2_2 also harboured enzymatic activity.

In the present study we showed that the recombinant ALT2_2 does not possess any enzymatic activity and that the recombinant ALT1 and 2 proteins possess about equal enzymatic activity when present towards alanine and 2-oxoglutarate in standardised settings, which add to the knowledge on ALT biochemistry without conflicting with previously published findings (5). The fundamental question of why a splice variant of ALT2 is produced is not addressed in this study. Since measurement of ALT activity is an indication of hepatic damage used in the clinic and preclinic, we focused on the catalytically active ALT2 and its presence in extrahepatic organs.

To understand the basic biochemistry of ALT1 and 2, enzymatic kinetics was studied. We found the enzymatic $\mathrm{K}_{\mathrm{m}}$ for alanine to be $\sim 4$-fold lower for ALT2 than for ALT1, while the $\mathrm{K}_{\mathrm{m}}$ for 2-oxoglutarate was similar between the enzymes. The $K_{m}$ for human endogenous ALT1 and 2 was reported only once before with somewhat different $\mathrm{K}_{\mathrm{m}}$ values, but the same ratio between ALT2/ALT1 (18). This $\mathrm{K}_{\mathrm{m}}$ ratio is also in agreement with data from rat cytosolic and mitochondrial ALT by Swick et al (2). All our enzymatic reactions were performed between $\mathrm{pH}$ 7.3-7.6 to mimic in vivo conditions. The $\mathrm{pH}$ optimum curves were reported for rat ALT proteins, in which the cytosolic ALT (corresponds to ALT1) has an optimum $\mathrm{pH}$ between 7.3-7.8 and the mitochondrial ALT (corresponds to ALT2) between $\mathrm{pH}$ 7.4-8.2 (2). Of the four substrates in the ALT reaction, alanine and pyruvate are likely to be rate limiting when considering in vivo 
Table II. ALT activity in human plasma before and after IP with ALT1 and 2 antibodies.

\begin{tabular}{lccc}
\hline Volunteers & $\begin{array}{c}\text { ALT activity } \\
\text { U/1 }\end{array}$ & $\begin{array}{c}\text { ALT activity after IP with ALT1 Ab } \\
\text { U/l }\end{array}$ & \% ALT activity removed with ALT1 Ab \\
\hline 1 & 20 & 1 & 95 \\
2 & 41 & 2 & 95 \\
3 & 35 & 4 & 89 \\
4 & 43 & 5 & 88 \\
5 & 29 & 3 & 90 \\
6 & 24 & 1 & 96 \\
7 & 58 & 7 & 88 \\
8 & 14 & 0 & 100 \\
9 & 23 & 2 & 91 \\
11 & 19 & 1 & 95 \\
\hline
\end{tabular}

concentrations (19). Our data show that ALT2 has a higher $\mathrm{k}_{\mathrm{cat}} / \mathrm{K}_{\mathrm{m}}$ than ALT1 for both alanine and pyruvate, which indicates that ALT2 is more active than ALT1 at lower concentrations of limiting substrates e.g. during starvation (19). DeRosa et al proposed that the function of ALT1 and 2 in vivo differs, and that mitochondrial ALT with a higher affinity for alanine, mainly functions in the direction of converting alanine to pyruvate, whereas the cytosolic ALT would function in both directions (20). However, our data suggest that ALT2 functions as a complementary system in the generation of pyruvate for gluconeogenesis during stressful conditions, such as starvation. The localisation of ALT2 to mitochondria would, according to this hypothesis, aid in pyruvate generation and prevent compromisation of the Krebs cycle.

In order to study the expression of catalytically active ALT2 in cells and tissues, we used the new N-terminal ALT2 antibody (11008) and showed that it recognized only the catalytically active ALT2 and not ALT2_2. We used four different ALT2 antibodies in an attempt to detect ALT2 in human liver extract using Western blot analysis. Despite this, we were still unable to detect any ALT2 in human liver extract.

One explanation for our failure to detect ALT2 in human liver is that ALT2 in human liver exists in such minute amounts that detecting it using Western blotting is not possible, and the use of enzymatic activity is, at present, the only way of detecting ALT2 in low expressing cells and cell compartments $(2,21)$. However, as in the previous work, we found high levels of ALT1 in the liver extract. This result is further supported by our purification of cell organelles. We found ALT1 in the cytosolic fraction of human hepatocytes, but were not able to detect ALT2 in any of these fractions (ER, mitochondria, cytosol) of hepatocytes. On the other hand, we were able to detect ALT2 in the ER and mitochondrial fraction, but not in the cytosol in cultured skeletal muscle cells. To our knowledge, this is the first report of the structural localisation of human ALT2 to the mitochondrial fraction. The very first indication that ALT exists in the mitochondria came from Hird and Rowsell who reported alanine aminotransferase activity in the soluble phase and particulate fraction of rat homogenates (22). Since then, other studies found ALT activity in the mito- chondria of rat, pig, guinea pig, chicken and insects $(20,23)$. Furthermore, proven localisation of ALT2 in the mitochondria in the liver of gilthead sea bream (Sparus aurata) was previously reported (24). Interestingly, the percent of ALT activity in the mitochondria between mammal species differs greatly. Swick et al reported that rat liver has a proportion of $90 \%$ in the cytosol and $2 \%$ of the total ALT activity in the mitochondria (2). To our knowledge, ALT subcellular localisation in human liver was only reported once. While the cytosolic fraction accounted for $86 \%$ of the ALT activity, $\sim 5 \%$ was found in the mitochondria (21). DeRosa et al, on the other hand, found $\sim 54 \%$ of the total ALT activity in mitochondria from pig liver and the remainder $(46 \%)$ in the cytosolic fraction (20). At the other extreme, chicken liver was shown to only have the mitochondrial ALT (20). Furthermore, while starvation in rat produced an increase in the specific activity of cytosolic ALT, but not mitochondrial ALT (25), Fujiwara et al demonstrated a 100 -fold increase in mitochondrial ALT in the liver of chickens during a 7-day starvation period (26). It is known that chickens maintain high blood glucose $(>10 \mathrm{mM})$, even during prolonged starvation, due to hepatic gluconeogenesis from alanine supported by mitochondrial ALT (26-28). Further work would have to focus upon ALT isoforms in liver and extrahepatic organs between different species and the relevance for function and application to liver injury in preclinical models (rat, mouse, dog, monkey etc.).

Using immunohistochemistry, we found high expression of catalytic ALT2 in heart muscle, skeletal muscle, smooth muscle in many different tissues, and in the islets of Langerhans. As a positive control for mitochondrial staining, an antibody against cytochrome oxidase IV subunit I was used. It was quite clear that ALT2 in skeletal muscle tissue was localised to mitochondria when compared to the staining pattern of cytochrome oxidase, which further supports our results from cultured skeletal muscle cells.

An interesting finding was the very dense ALT2 staining in cardiomyocytes. Mild increases of serum ALT levels during myocardial infarction occurs in many patients (29). The plasma ALT activity in these patients reaches 100-200 U/1 and originates from the heart tissue (30). Our data presented here, 
together with the weak detection of ALT1 in heart tissue (6) indicates release of ALT2 from damaged cardiomyocytes.

Our finding of ALT2 expression in the islets of Langerhans is also linked to clinical observations. Diabetes mellitus patients undergoing pancreatic islet transplantation have self limiting and mild ALT increases (transaminitis) for unknown reasons (31). The data presented here provide a hypothesis for the serum ALT increase as a possible ALT2 leakage from dying islet cells.

By using immunoprecipitation of ALT1 from human serum and plasma, we found a higher degree of catalytically active residue in the plasma preparation compared with the serum preparation. The reason for this is unknown but one factor contributing is the instability of ALT2 in a serum environment, due to time in preparation. Another possibility is the stabilisation factors present in plasma and not in serum, which our data in Fig. 1d indicate. We and others have found that recombinant catalytic ALT2 rapidly loses its enzymatic capacity when stored in serum at $37^{\circ} \mathrm{C}(32)$. ALT2 protein was much more stable at room temperature, and even more at $4^{\circ} \mathrm{C}$. At $-80^{\circ} \mathrm{C}$ we found both ALT1 and 2 completely stable when tested one week later. In contrast ALT1 is much more stable than ALT2, and showed some loss of activity only at $37^{\circ} \mathrm{C}$. In addition, we investigated this further using a buffer containing glycerol and albumin. In this buffer ALT2 still lost its catalytic capacity, but at a much slower rate than in serum. Stabilisation of rat mitochondrial ALT with glycerol was previously reported (2). We found that adding alanine to the test tube slows down the process. However, adding a cocktail of protease inhibitors to the serum, had no effect on slowing down ALT2 enzymatic activity. Rat liver mitochondrial alanine aminotransferase is known to be a very unstable enzyme, a property that prevented efforts to purify it (2). Use of trehalose in the extraction was reported to improve mitochondrial ALT stability, while protease inhibitors were without effect, which is in line with our observations of human ALT2 (33).

So, by preparing plasma samples on ice and quickly freezing them at $-80^{\circ} \mathrm{C}$, ALT residual activity after IP was higher than the serum in the normal individuals tested. We immunoprecipitated ALT1 from plasma samples and then remeasured ALT activity, a concept used to measure the cytosolic and mitochondrial forms of AST in plasma or serum (34). As seen from Table II, the major fraction of ALT isoform in plasma of normal healthy volunteers is ALT1, however all ALT activity cannot be removed with the ALT1 antibody when plasma is used compared to serum preparations. However, this residual ALT activity is removed with an ALT2 antibody, supporting the notion of ALT2 in plasma preparations. However to show that plasma contained both ALT1 and 2, ALT1 was precipitated from human plasma, and the elute was loaded on a gel and a band was detected at the predicted molecular weight. Then, the remaining precipitate was also loaded on a gel and subjected to detection using two ALT2 antibodies. A band was detected at the predicted molecular weight $(58 \mathrm{kDa})$. However, the band was much weaker than ALT1, even using ECL advance detection system, known to have a detection limit down to 1 picogram.

In conclusion, we have specifically detected the catalytically ALT2 in different human tissues (such as the heart, smooth skeletal muscles and pancreas but not in the liver) and in human plasma for the first time. We also showed that ALT2 is localised to the mitochondria of skeletal muscle cells and that ALT1 is the cytosolic form of ALT in hepatocytes.

We also developed a rapid clinical method based upon the routine standard method, in which measurement of ALT1 and 2 in a given human plasma sample is achieved. Application of this method to clinical samples fast track the problem solving activities of drug projects (or help a physician) in directing focus towards or away from the liver. Future work has to focus upon validating this IP/activity method of selective ALT1 and 2 measurement described in this study, before testing the hypothesis, if a tissue injury in an ALT2 rich organ impacts the standard ALT activity in the circulation and selectively being measured.

\section{Acknowledgements}

We would like to thank Anette Wallstedt for performing the blood withdrawal from healthy volunteers and Gunilla Rylander for performing all ALT activity measurements.

\section{References}

1. De Rosa G, Burk TL and Swick RW: Isolation and characterization of mitochondrial alanine aminotransferase from porcine tissue. Biochim Biophys Acta 567: 116-124, 1979.

2. Swick RWBPLSJL: The metabolism of mitochondrial proteins. I. Distribution and charachterization of the isozymes of alanine aminotrnasferase in rat liver. J Biol Chem 240: 3334-3340, 1965.

3. Takeda YIATHIH: The biochemistry of animal cells. The effect of corticoteroids on leakage of enzymes from dispersed rat liver cells. J Biol Chem 239: 3590-3596, 1964.

4. Ishiguro M, Takio K, Suzuki M, Oyama R, Matsuzawa T and Titani K: Complete amino acid sequence of human liver cytosolic alanine aminotransferase (GPT) determined by a combination of conventional and mass spectral methods. Biochemistry 30: 10451-7, 1991.

5. Yang RZ, Blaileanu G, Hansen BC, Shuldiner AR and Gong DW: cDNA cloning, genomic structure, chromosomal mapping, and functional expression of a novel human alanine aminotransferase. Genomics 79: 445-450, 2002.

6. Lindblom P, Rafter I, Copley C, Andersson U, Hedberg JJ, Berg AL, Samuelsson A, Hellmold H, Cotgreave I and Glinghammar B: Isoforms of alanine aminotransferases in human tissues and serum - differential tissue expression using novel antibodies. Arch Biochem Biophys 466: 66-77, 2007.

7. Sohocki MM, Sullivan LS, Harrison WR, Sodergren EJ, Elder FF, Weinstock G, Tanase S and Daiger SP: Human glutamate pyruvate transaminase (GPT): localization to 8q24.3, cDNA and genomic sequences, and polymorphic sites. Genomics 40: 247-252, 1997.

8. Karmen AWFLJS: Transaminase activity in human blood. J Clin Invest 34: 126-131, 1955.

9. Draper RP, Waterfield CJ, York MJ and Timbrell JA: Studies on the muscle toxicant 2,3,5,6-tetramethyl p-phenylenediamine: effects on various biomarkers including urinary creatine and taurine. Arch Toxicol 69: 111-117, 1994.

10. O'Brien PJ, Slaughter MR, Polley SR and Kramer K: Advantages of glutamate dehydrogenase as a blood biomarker of acute hepatic injury in rats. Lab Anim 36: 313-321, 2002.

11. Valentine BA, Blue JT, Shelley SM and Cooper BJ: Increased serum alanine aminotransferase activity associated with muscle necrosis in the dog. J Vet Intern Med 4: 140-143, 1990.

12. Waner T and Nyska A: The toxicological significance of decreased activities of blood alanine and aspartate aminotransferase. Vet Res Commun 15: 73-78, 1991.

13. Dhami MS, Drangova R, Farkas R, Balazs T and Feuer G: Decreased aminotransferase activity of serum and various tissues in the rat after cefazolin treatment. Clin Chem 25: 1263-1266, 1979.

14. Yamada RH, Wakabayashi Y and Iwashima A: Inhibition of serum aspartate aminotransferase induced by isoniazid administration in mice. Acta Vitaminol Enzymol 6: 289-293, 1984. 
15. Jadhao SB, Yang RZ, Lin Q, Hu H, Anania FA, Shuldiner AR and Gong DW: Murine alanine aminotransferase: cDNA cloning, functional expression, and differential gene regulation in mouse fatty liver. Hepatology 39: 1297-1302, 2004.

16. Lindena J, Sommerfeld U, Hopfel C and Trautschold I: Catalytic enzyme activity concentration in tissues of man, dog, rabbit, guinea pig, rat and mouse. Approach to a quantitative diagnostic enzymology, III. Communication. J Clin Chem Clin Biochem 24: 35-47, 1986.

17. Ladue JS and Wroblewski F: Serum glutamic pyruvic transaminase SGP-T in hepatic disease: a preliminary report. Ann Intern Med 45: 801-811, 1956.

18. Gubern G, Imperial S, Busquets $M$ and Cortes A: Partial characterization of the alanine aminotransferase isoenzymes from human liver. Biochem Soc Trans 18: 1288-1289, 1990.

19. Williamson DH, Lopes-Vieira O and Walker B: Concentrations of free glucogenic amino acids in livers of rats subjected to various metabolic stresses. Biochem J 104: 497-502, 1967.

20. DeRosa G and Swick RW: Metabolic implications of the distribution of the alanine aminotransferase isoenzymes. J Biol Chem 250: 7961-7967, 1975.

21. Gubern G, Imperial S, Busquets M and Cortes A: Subcellular distribution of alanine aminotransferase activity in human liver. Biochem Soc Trans 18: 1287-1288, 1990.

22. Hird FJ and Rowsell EV: Additional transaminations by insoluble particle preparations of rat liver. Nature 166: 517-518, 1950.

23. Pette D and Luh W: Constant-proportion groups of multilocated enzymes. Biochem Biophys Res Commun 8: 283-287, 1962.

24. Meton I, Egea M, Fernandez F, Eraso MC and Baanante IV: The $\mathrm{N}$-terminal sequence directs import of mitochondrial alanine aminotransferase into mitochondria. FEBS Lett 566: 251-254, 2004.

25. Swick RW, Barnstein PL and Stange JL: The metabolism of mitochondrial proteins. II. The response of the isozymes of alanine aminotransferase to diet and hormones. J Biol Chem 240: 3341-3345, 1965.

26. Fujiwara S, Sakuraba $\mathrm{H}$ and Noguchi T: Identification of chicken liver mitochondrial alanine: 2-oxoglutarate aminotransferase and its response to starvation. Arch Biochem Biophys 310: 497-503, 1994.
27. Davison TF and Langslow DR: Changes in plasma glucose and liver glycogen following the administration of gluconeogenic precursors to the starving fowl. Comp Biochem Physiol A 52: 645-649, 1975.

28. Brady LJ, Romsos DR, Brady PS, Bergen WG and Leveille GA: The effects of fasting on body composition, glucose turnover enzymes and metabolites in the chicken. J Nutr 108: 648-657, 1978.

29. Bang NU and Ladue JS: Comparison of the serum glutamic oxaloacetic transaminase, serum glutamic pyruvic transaminase and lactic dehydrogenase activity following acute myocardial infarction. Dis Chest 41: 384-391, 1962.

30. Giesen PL, Peltenburg HG, de Zwaan C, Janson PC, Flendrig JG and Hermens WT: Greater than expected alanine aminotransferase activities in plasma and in hearts of patients with acute myocardial infarction. Clin Chem 35: 279-283, 1989.

31. Barshes NR, Lee TC, Goodpastor SE, Balkrishnan R, Schock AP, Mote A, Brunicardi FC, Alejandro R, Ricordi C and Goss JA: Transaminitis after pancreatic islet transplantation. J Am Coll Surg 200: 353-361, 2005

32. Liu L, Zhong S, Yang R, Hu H, Yu D, Zhu D, Hua Z, Shuldiner AR, Goldstein R, Reagan WJ and Gong W: Expression, purification, and initial characterization of human alanine aminotrasferase (ALT) isoenzyme 1 and 2 in High-five insect cells. Protein Expr Purif 60: 225-231, 2008.

33. Mukorah F, Razunguzwa B and Masola B: Stabilization of rat liver mitochondrial alanine aminotransferase with ethanol and trehalose. Cryobiology 37: 300-308, 1998.

34. Wada H, Teranishi H, Kagamiyama H, Ohyanagi H, Shirakawa M Mitsuno T, Fuse K and Sawada Y: A simple immunological method for differential determination of serum glutamicoxaloacetic transaminase isoenzymes. (I) Using anti-humanGOT antibody. Med J Osaka Univ 29: 181-190, 1978. 